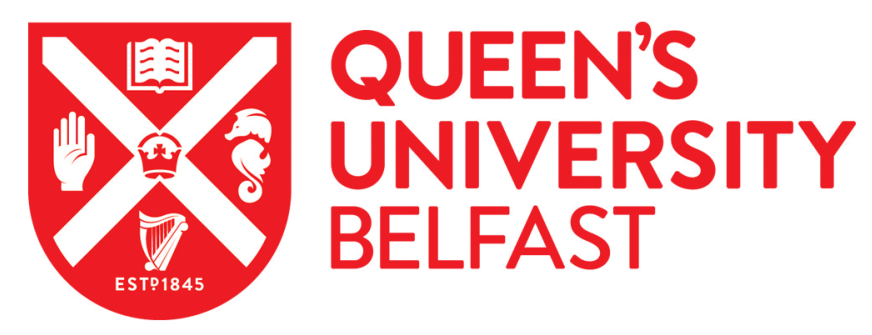

\title{
Whose Sins Do the Brethren Confess? The Problem of Sin as the Problem of Expiation
}

Webster, J. (2019). Whose Sins Do the Brethren Confess? The Problem of Sin as the Problem of Expiation. Ethnos. https://doi.org/10.1080/00141844.2019.1582547

\section{Published in:}

Ethnos

\section{Document Version:}

Peer reviewed version

Queen's University Belfast - Research Portal:

Link to publication record in Queen's University Belfast Research Portal

\section{Publisher rights}

Copyright 2019 Taylor \& Francis. This work is made available online in accordance with the publisher's policies. Please refer to any applicable terms of use of the publisher.

\section{General rights}

Copyright for the publications made accessible via the Queen's University Belfast Research Portal is retained by the author(s) and / or other copyright owners and it is a condition of accessing these publications that users recognise and abide by the legal requirements associated with these rights.

Take down policy

The Research Portal is Queen's institutional repository that provides access to Queen's research output. Every effort has been made to ensure that content in the Research Portal does not infringe any person's rights, or applicable UK laws. If you discover content in the Research Portal that you believe breaches copyright or violates any law, please contact openaccess@qub.ac.uk. 


\title{
Whose sins do the Brethren confess? The problem of sin as the problem of expiation
}

\author{
Joseph Webster \\ j.webster@qub.ac.uk \\ School of History, Anthropology, Philosophy, and Politics \\ Queen's University Belfast
}

UK

\begin{abstract}
Among Brethren fisher families in Gamrie, northeast Scotland, professional clergy and written liturgy are held to be blasphemous denials of the true workings of the Holy Spirit. God, I was told, chooses to speak through all born-again (male) persons, unrestricted by the vain repetitions of lettered clerics and their prayer books. In this context, confession of one's own sin is a private and pointedly interior affair. In Gamrie, not only did every man seek to be his own skipper, but also his own priest. Yet, much of Brethren worship is given over to ritualised acts of confession. So whose sins do the Brethren confess, and to what end? This article argues that among the Brethren of Gamrie, such acts involve confessing not one's own sin, but the sins of a 'sick' and 'fallen' world. More than this, by attending to the anthropological and theological processes of confessing the sins of another, we see a collapse in the distinction between confiteor and credo that has so dogged anthropological studies of Christianity. In Brethren prayer and bible study, as well as in everyday gossip, the "I confess" of the confiteor and the "I believe" of credo co-constitute one another in and through evidences of the 'lostness' of 'this present age'. But how, if at all, does this solve 'the problem of sin'? This article suggests that, with the ritual gaze of confession turned radically outward, Brethren announcements of global wickedness enact (in a deliberate tautology) both a totalising call for repentance from sin, and a millenarian creed of the imminent apocalypse. Here, the problem of ritual can be understood as the problem of (partially failed) expiation.
\end{abstract}

Key words: [Confession, Prayer, Sin, Theology, Apocalypse, Scotland] 
For the larger part of the two millennia of the Christian era the problem of evil, and closely linked with it, the concept of sin have played an important, and even in certain periods even a crucial role in Western philosophical thinking.

(Furer-Haimendorf 1974: 539)

\section{Introduction}

Satan is very intelligent and he does use men. At the present time I think we do see the power of Satan. People say that we don't see it today, but we do. Persons do things that can only come from Satan himself - they do terrible things and there is no one able to bring them under control. We have something very close to this [demonic possession] in the drug problem in Fraserburgh and the only one who can deal with it, really, is the Lord Jesus. When the Christians go [at the Rapture] the Holy Spirit goes, and the government will not be able to control things, so I would think Satan would have almost the right of way. And the demons are his agents, and he will take control of men, even as he is doing today, bringing terrible things. There's nobody a match for Satan but Jesus. Satan knows his time is short and he's worse today now than when we were young; his power is definitely more evident. Through it, we should see the hopelessness of man's position away from God and under the power of Satan. We have to realise that we are no match for Satan; sometimes we think we are, but we're not. We have to realise that we are on Satan's territory. The world is going into darkness; the state of the world at the present time, we see it getting worse, we realise that.

(Seatown Close Brethren 'Bible Reading', Gamrie, Northeast Scotland, August 2009) 
The words above were spoken by Alec ${ }^{1}$, a 'Close Brethren' man in his eighties, during one of Gamrie's weekly 'bible reading' meetings. These meetings were times of informal yet very serious discussion of 'the scriptures', as they were imagined to relate to present day life along Scotland's Aberdeenshire coast. The Seatown assembly, of which Alec was a member, was one of four Brethren groups in the village, and held its meetings in a modest corrugated iron and wooden hall up a narrow close, just yards from the sea. Here, the Seatown Brethren would gather to 'break bread', pray, sing hymns, and hear 'The Word' taught to and discussed by 'the saved', and well as being preached at the 'unsaved'. It is this second to last category of exposition - the discussion-based 'bible reading' - that I have quoted from above, drawn from a conversation about Luke chapter four, where Jesus heals a man with an 'unclean demon'. But what did Alec mean when he asserted that 'persons do things that can only come from Satan himself'? Why, in this context, might drug addiction be thought of as akin to demonic possession? In what sense is the world 'going into darkness'? And what, if anything, can this tell us about Christian confession? It is questions such as these that this article seeks to explore.

Drawing inspiration from Robert Hertz's (1922 [1994]) seminal but little read essay 'Sin and Expiation in Primitive Societies'2 and applying it to Scottish Protestantism, I want to call into question conventional anthropological understandings of confession as that which is fixated upon 'the production of inner truth' (Carr 2013). Taking a step away from these explicitly Foucauldian notions of confession (e.g. Foucault 1993. Also Carr 2013. cf. Webster 2008) seems a helpful way of expanding our understanding of sin and expiation - as Hertz himself did almost a century ago - to encompass much more than 'automatic outward reflections of

\footnotetext{
${ }^{1}$ All names have been changed.

${ }^{2}$ As translated by Robert Parkin (1994).
} 
reflexively realized inwardness' (Carr 2013: 35). Indeed, as I will argue for the Brethren of Gamrie, far from 'persist[ing] in the belief that confession lets the things inside out into words' (ibid. 47), for these ultra-conservative Scots-Protestants, the opposite is true, namely confession lets the things outside in into the body - a body that nonetheless remains full of language and other signs. Thus, rather than offer the idle promise of transcending the 'dual symbolic classification' (Needham 1973) of any inside/outside dichotomy, I set myself the (perhaps equally immodest) task of reversing the direction in which confessional 'signs' are imagined to move, that is, from inside-out to outside-in. But first, a word of context.

\section{Gamrie: Present and Future}

For the Christians of Gamrie, Northeast Scotland, and most especially for the Brethren groups that made up four of the village's six churches, the world in which they (and all humans) lived was imagined to be 'full of sin', to the point of grievous 'sickness'. So serious was this 'sin sickness', my informants explained, that it would very soon provoke Jesus' return in Final Judgement - a return, crucially, that would only occur after 'the saved' had vanished from the earth at the point of the 'Rapture'. While of huge cultural salience among American Christian fundamentalists ever since the publication of LaHaye's bestselling Left Behind apocalyptic novel series ${ }^{3}$ (cf. Frykholm 2004, Harding 2000), it seems important to note that this pre-tribulational, pre-millennial theology of the 'end times' was actually invented by founding member of the Brethren Movement, John Nelson Darby (1800-82). Among Gamrie's Christians, then, a less glamorised but no less potent eschatological vision of humanity's present and future dominated local interpretations not only of religion, but also of economics and family life. I have described these social processes in detail elsewhere

\footnotetext{
${ }^{3}$ A success story that has seen the sale of over 65 million books, a Hollywood film remake starring Nicholas Cage, a spin-off television series by HBO, four video games, and a graphic-novel series.
} 
(Webster 2013a: 57-72); a short summary will have to suffice, providing the minimum context required to situate the ethnographic and theoretical commentary that follows.

Gamrie, in brief, was experiencing three related pressures - a 'triple pinch' of economic, demographic and eschatological change - that were connected to Gamrie's industrial makeup as a fishing village, and its religious makeup as dominated by the Brethren. In terms of economy, the financial costs of staying within the fishing industry were rapidly increasing, as the prices of building and running boats outstripped the price of prawns. As a result, 'constant competition to cut costs between fleets, boats and buyers selling to markets around the world drove seafood prices down and meant that boats had to catch more and more 'bulk' in order to make bank payments, buy fuel, maintain the boat and pay crew (McCall Howard 2017: 177. See also Nadel-Klein 2003: 141). Increasing EU regulations via the Common Fisheries policy (CFP) squeezed profitability further, where in addition to a complex quota system, the CFP regulated the number of days fishermen could be at sea, what gear they could use when trawling, and what minimum prices they could accept at market. Compliance was strictly enforced, with skippers required to submit extensive paperwork detailing where they had fished and what they had caught.

Importantly, such EU regulation was seen by my Christian informants as a clear example of demonic attack. My informants detailed how the devil was seeking to destroy the 'life and witness' of the village by destroying its fishing industry, while at the same time enacting a much bigger satanic plot to enslave humanity by gaining control over world food supplies. Fierce competition between boats, moreover, led some crews to bankruptcy and others to an increased (and thus more profitable) market share. Some of Gamrie's churches had also fallen 
on hard times financially as a result of these demographic changes, with fewer working-age families resident (and even fewer, willing) to contribute substantially to weekly congregational collections. Thus, while Gamrie as a whole was certainly not facing the 'last days' of its fishing industry, many individual fisher-families were. It was this fact that threatened Gamrie's claim to being a viable Christian fishing village, as opposed to an economically and spiritually struggling ex-fishing village sustained by heritage tourism and the monetisation of memory (Nadel-Klein 2003: 171-173).

In terms of demography, Gamrie's churches and fishing crews were ageing. Here the general pattern, with some exceptions, was for young men either to leave the village to berth their boats in the larger town of Fraserburgh, or leave the fishing industry entirely to take jobs in the North Sea oil industry, most commonly on the supply boats, where pay was often higher and working conditions easier. With large numbers of young Fraserburgh-based fishermen and oil workers enjoying higher wages and shorter working hours, the popularity of heroin overtook that of alcohol, as the newly affordable drug became a common way to spend disposable income and leisure time. With news of a growing heroin epidemic came Fraserburgh's unenviable reputation for being 'Scotland's drug capital' - a title which reinforced my Brethren informants' sense that 'the power of Satan' was growing and that, as a result, the world was 'going into darkness'. Of those working-age fishers who stayed in Gamrie, many stopped attending any place of worship, often because they (or their skipper) no longer followed the Sabbatarian principles of their forefathers, choosing instead to fish also on Sundays in increasingly relentless efforts to repay the enormous mortgages they had on their boats. Elderly congregations were thus shrinking congregations, with those in their seventies and eighties 'passing into glory' and noticeably not being replaced by a new generation of bible 'preachers' and 'teachers'. My presence among Gamrie's Brethren 
assemblies was out of the ordinary in this respect, indeed, I often found that at such gatherings I was the youngest by approximately five decades.

In terms of eschatology, time was regarded by my Christian informants as desperately short, for Jesus would soon return in judgement, taking the righteous into heaven and casting the wicked into hell. The task of communicating the imperative need to receive born-again salvation during the rapidly ending 'day of grace' increasingly fell to the elderly, for the young, I was told, had 'turned their backs on God' in their quest for worldly riches and leisure. No longer do large sections of the fishing community on shore tune in to listen to evangelical hymns being sung sea every night by large sections of the Fraserburgh and Peterhead fleets over maritime radio. With 'the Christian aspect of fishing [having] dwindled in significance, young men in general show less interest in religion and listen to commercial radio or recordings whilst as sea' (Wilkins 2015: 148). In Gamrie, Grandparents now prayed mostly for the salvation of their very young grandchildren, having become convinced that their own (now grown-up) children had made a decision to 'reject Christ'. Thus, while it was well known to my elderly Christian informants that the religion of Gamrie, suffering under both economic and demographic pressures, was going extinct, this realisation paled into insignificance as compared to their greater eschatological realisation that the whole world was soon to be consumed by fire from heaven. Such was the position from which the Brethren of Gamrie lived their lives - a position partly defined by the uncertainties of economic and demographic decline, as framed by the larger (and utterly certain) soon arrival of eschatological deliverance or oblivion.

\section{A 'Sin Sick' World}


According to my informants, the evidence for this impending-judgement-giving-way-tooblivion were clearly visible to all who cared to look - the global economic recession, the spread of militant Islam, the social acceptance of abortion, divorce, and homosexuality, the spread of drug addiction, the popularity of the 'false religion' of climate change (Webster 2013b), the liberalisation and numerical decline of Christian churches in the West, political and military threats made against Israel - all these and many more were held to be undeniable 'signs of the times' ${ }^{4}$. As such, my Christian informants looked upon the 'modern world' in which they lived, and shuddered; evil and sin were everywhere, and being contaminated by its sickness was said to be inevitable. How, then, in such a world, did my informants maintain their own moral cleanliness? By regular confession of personal sin, or by other means?

For Gamrie's Brethren, the solution to this contamination was found not so much in acts of personal confession as it was in acts of separation. Indeed, my Brethren informants organised much of their daily lives - to different degrees and in different ways, depending on which sect they belonged to - around what they referred to as 'the doctrine of separation' (see Webster 2018). While described locally as both a 'doctrine' and a 'principle', this moral code was eminently practical, delineating sometimes in very specific terms to what extent and in what contexts Brethren could engage with 'the world', its people, and their activities. Most, for example, did not vote as a matter of conscience, viewing party politics as a sphere of satanic rule. Similarly, pubs, cinemas, and dance halls were all shunned as 'the devil's lair'. Many Brethren, furthermore, refused to watch television or listen to the radio, and some chose not to read newspapers - for these were methods, I was warned, of 'bringing the world

\footnotetext{
${ }^{4}$ My use of this phrase, drawn from Gamrie's Christian lexicon, has a very different meaning to that intended by Carr (2013) in the title of his recent article. Carr refers to Pope John XXIII's call to 'reconcile the Church's teachings with contemporary social issues and actors' (2013: 35). In contrast, among Gamrie's Brethren, as in Protestant fundamentalist culture generally, a 'sign of the times' refers to any contemporary observation or occurrence that is taken as indicative evidence of the soon to arrive end of the world.
} 
into your home'. To fail in these avoidances would mean being guilty of sin, since, as one informant succinctly put it, 'the world is the kingdom of Satan'.

All such avoidances, which for Durkheim formed a key part of the 'negative cult' (1912: 299308), extended not just to the (ostensibly) 'profane' world of the ballot box or the pub, but also to the more obviously 'sacred' sphere of worship. 'Separation' from other Christians, (including from other Brethren sects), was, therefore, another important aspect of this doctrine, with interdenominational church work in the village being virtually non-existent as a result. This also caused difficulties regarding attendance at village celebrations, such as weddings, with some Brethren refusing to enter any place of worship with which they were not directly linked by membership. Navigating the requirements of this doctrine was not easy, with some Brethren being accused of taking separation too far, as exemplified in local tales of daughters refusing to attend their own mother's funeral, or of parents refusing to eat at the same table as their children.

Regardless of the effects of such 'extreme' cases, pursuing separation was understood to be about safeguarding of the moral purity of one's self and one's household, for, as my informants often sought to remind me, 'holiness is separation from evil'. As one Close Brethren informant explained: “apostasy is rife today; you won't cure it, you have to withdraw from it. Where there is evil, there is only one remedy - you have to withdraw from it!" This task, however, was locally held to be far more difficult today than it had been in the past, due to the ways in which 'the world' - by way of eschatological imperative and prophetic design - was said to be sliding inexorably into godlessness. As such, the doctrine of separation was also a doctrine of sin and of the end times - and so too was its practical 
application. 'Our purpose', one Brethren man explained, 'is to bear a testimony to God in this evil and wicked generation that we are living in; a terrible world that is getting worse every day'. But what did it mean, in this context, for Gamrie's Brethren 'to bear a testimony'? How had these Christians come to the firm conclusion that the world 'is getting worse every day', by, in Alec's words, 'going into darkness'? It seems that before answering these questions, we need to more carefully consider what, in anthropology, we might mean by - or, perhaps better said, where we might look for - the content of theological concepts such as 'sin', 'confession', and 'expiation'.

\section{Anthropologies and Theologies of Morality: Sin, Confession and Expiation}

Joel Robbins (2012), in a considered and insightful essay that provides a detailed reflection upon Fabion's (2011) An Anthropology of Ethics, as well as his own hopes for the development of 'the anthropology of morality', calls to his readers' attention the striking absence, within the ethnographic record, of 'original formulations concerning the nature of morality as a social or cultural formulation' (Robbins 2012: 1). One marked exception to this rule - not cited by Robbins - is J. K. Campbell's beautiful ethnography Honour, Family, and Patronage: A Study of Institutions and Moral Values in a Greek Mountain Community. First published in 1964, this ethnography seems to stand as a relatively early example of the kind of anthropology Robbins is calling for. Not only does Campbell provide a detailed ethnographic consideration of Sarakatsani moral characteristics, virtues, and ideals, but also shows how these relate to the daily practices of shepherding and raising families. His focus is on how the Sarakatsani seek to live in ways that honour men and women, cultivate ways to God, and avoid the attentions of the Devil. For our present purposes, it is of particular interest to note that Campbell's commentary on Sarakatsani notions and experiences of sin is 
extensive, receiving a total of 25 mentions in his index, several of which span a number of pages.

Still, one swallow does not a summer make, and given the genuine paucity of ethnographic reflections upon morality, Robbins' general comment seems fair. So too does his next suggestion, that, regarding the development of this anthropological subfield, 'a light drizzle of preliminary interest [in the early 2000s] has become more of a storm' (ibid.) over the last ten years. Robbins persuasively argues that one of the main themes of this more recent scholarship on morality concerns 'issues of freedom', as seen in the work of Faubion (2011) and Laidlaw (2002). Here, the influence of Foucault on Faubion is drawn out, as are sociologically orientated concerns about the concomitant focus on the individual and her (occidental) 'self-understandings' (Robbins 2012: 3) - understandings, importantly, that tend to de-emphasise 'the social patterning of action' (ibid.). Robbins, however, makes it clear that he thinks Faubion's Foucauldian theory of ethics helps him escape this trap, for 'Greek freedom, like all of the kinds of freedom anthropologists generally want to discuss, is a socially situated and conditioned freedom' (ibid. 4).

While not wanting to comment directly upon Faubion's work in particular, my sense of the general implications of having a Foucauldian ghost in the anthropology-of-ethics-cummorality machine is, in short, that it may still be insufficiently 'social'. In an earlier consideration of Foucault's work on confession (Webster 2008: 74), I concluded on precisely this point by suggesting that it was Bourdieu and not Foucault who offered anthropology a properly sociological (that is, collectivist) view of the practice of confession. Carr's (2013) Foucauldian analysis of post-Vatican II confessional manuals seems to bear my concern out, 
focusing, as she does, on how such texts help produce a version of confession whereby 'sin is rendered an icon of the confessant's inner state' (ibid. 37) by engaging in a highly personal ‘internal inquisition' (ibid. 38). In my reading of Carr, sin is rendered as a series of specific and singular transgressions that an individual confessant has committed against God. Thus, confession likewise becomes known as a series of personal admissions, which are 'understood to be automatic outward reflections of reflexively realized inwardness' (ibid. 35). Finally, the expiation that confession of sin brings is therefore understood to be based on a 'linguistic ideology [which] promises its adherents a seductive payoff: to the extent that a confession successfully refers to inner states, it also cleanses the conscience of them' (ibid. 40). Such is the privatised and individualised nature of contemporary confession as imagined within a Foucauldian paradigm of semiotic self-surveillance and self-cultivation.

But what if sin referred not to individual transgressions, but to a general state of moral decay that the entire world was said to be infected by? What if confession, instead of requiring the private itemisation of inwardly hidden personal sins, actually required a corporate discussion of the collective sins of others? And what if expiation was achieved not privately through the externalisation of 'inner states', but rather through the public internalisation of external 'signs of the times'? Would this afford us a more robustly social view of these concepts and their cultural processes? I want to suggest that it would, and I want to show this by returning to the specifics of the ethnographic data I collected among my Brethren informants. But before I do so, I want to lay out a rather different series of theoretical premises to those handed to us by Foucault by returning to the early work of Robert Hertz (1994), and to his unfinished thesis on sin and expiation. 


\section{Hertz on Sin and Expiation}

Christianity in its totality can be envisaged as a grandiose attempt by man to see his nature, duty and destiny in terms of sin and expiation (Hertz 1994: 58)

So says Hertz, summarising his commentary on 'the essentials... which govern Christian conscience and conduct' (ibid. 57). This ethnological work - left incomplete as a result of Hertz being killed in action in France in 1915 at the age of 33 - sought to come to terms with the social nature of moral transgression and thus the "mystery of pardon, the absolute annihilation of something real', that is, sin. The main finished portion of the text that survives is the introduction, in parts further reconstructed by Mauss, and later translated and edited by Robert Parkin (1994). In true Durkheimian fashion, this opening chapter is littered with various definitions of both $\sin$ and expiation. For Hertz, as for, I suspect, many anthropologists today, 'sin', being a social phenomenon, is to be understood not so much in terms of what it is but rather in terms of what it does. Thus:

In reality, sin immediately produces a profound and substantial change in the soul of its author. Its action can be compared to the action of baptism, which renews to the very depths the being of the neophyte, but it is an ominous sacrament, producing death and damnation. [...] Sin is thus to be defined as a transgression which, by the sole fact that it is carried out, tends to bring about death (Hertz 1994: 72, 99)

After further discussion, and several attempts at reaching a definition that separates sin from 'crime', and from offences against 'honour', Hertz settles on the following: 
Sin is a transgression of a moral code, which is considered to involve, by virtue of itself, disastrous consequences for its author, and which concerns the religious society exclusively (ibid. 108)

Yet even this careful definition is necessarily provisional, because, despite the influence of Durkheim (his would-be supervisor), Hertz seems to implicitly realise that many societies do not so easily parse the sacred and profane. Indeed:

in societies in which... religious life is diffused throughout the whole of the social body... we must expect to see the transgression of all the laws acknowledged by common belief being assimilated to $\sin ($ ibid. 110)

This is no trivial point, revealing, as it does, Hertz's very general conceptualisation of sin, understood, as Parkin suggests, as 'impurity in all its forms' (1994: 17), or, more generally still, as 'the dark side of humanity' (Hertz 1994: 17; Parkin 1994, 2008). Indeed, as Parkin points out, one may take this highly generalised trope of sin as characteristic of all of Hertz's work in one sense or another. Thus, death, according to Hertz's ethnology, is explained by societies that lack a concept of 'natural death' as ultimately being the product of the wilful sin of an unknown 'other' (1960). Likewise, Hertz's work on the pre-eminence of the right hand (1973) suggests that left-handedness (and the left side of all polarities) comes to stand for all that which is impure and thus sinful. My point here is not to claim that the concept of $\sin$ is the only possible interpretive lens through which we may read Hertz's work, but rather to indicate the way in which sin (as both a conceptual category and an empirical phenomenon) looms large in Hertz's work. More than this, I want to suggest that we find within Hertz's 
highly generalised definition of sin its main analytical strength (as opposed to weakness) precisely because it furnishes us with the intellectual tools necessary to reconstruct sin as an unavoidably social and pointedly outwards-facing experiential reality.

Key to understanding this point is the realisation that, for Hertz, sin, understood as a social phenomenon, is not bounded by the personal culpability of any individual transgressor. This is because the effects of sin are not thought to solely concern any particular 'profound and substantial change in the soul of its author' (Hertz 1994: 72) but rather 'concerns the religious society exclusively’ (ibid. 108. Emphasis added). Hertz's efforts here, I think, are not simply directed toward a locating of sin within its social context (by stating where sin is), but also seek to expose the functioning of sin within a collective consciousness (by stating what $\sin$ does). Sin, then, is located within the 'religious society', whereas crime, for example, would be located within the juridical society. Yet the question remains, what does sin actually do according to Hertz? If $\sin$ is not bound to any notion of individual culpability, how does it function (or operate) within a collective 'religious society'?

This shift in emphasis - from 'religion' to 'society' - clarifies how Hertz imagines sin operates, that is, by producing both 'death and damnation' (ibid. 72) not only for the individual, but also for the group. Indeed, sin, being a social phenomenon, is produced not by the penitent, but by the Church, that is, by society. Sin depends on its recognition by the sinner, a recognition that is itself dependent upon the existence of the Church (Parkin 1996: 25). Thus, for Hertz: 
if there were not law promulgated by God and taught by the Church... there would be no breach of the law and consequently no $\sin . .$. It is not the sinner who creates sin; it is sin, i.e. the performance of an act forbidden by law, that makes the sinner what he is (Hertz 1994: 71)

The result is that, within the theologically conservative Christian cosmology that Hertz's is discussing - and within which I conducted my fieldwork ${ }^{5}$ - not only is sin created by but also experienced by society as a whole. Gone is the hyper-individualisation of $\sin$ and confession as discussed by Carr (2013) and framed by Foucault (1993). Here, rather, the signs and consequences of sin find themselves turned radically outward, as that which 'defiles the world' (Hertz 1994: 74) - words written by Hertz but surely echoed by Gamrie's Brethren. It is in this sense that 'Christianity in its totality can be envisaged as a grandiose attempt by man to see his nature, duty and destiny in terms of sin' (ibid. 58), for 'the sinner feels oppressed by his sin, even if he is not directly responsible for it, for example, the sin of Adam or of one's parents' (Parkin 1994: 25. Emphasis added. cf. Sahlins 1996; Furer-Haimendorf 1974). Sin, then, is something that originates in the collective; an inherited disease that resides within any culture or group that affirms its existence as a moral category, which, once affirmed as such, unleashes the shared effects of its world-defiling 'sickness'.

But what of the ultimate effects of this 'sin sickness', as my informants referred to it? For the Brethren of Gamrie, as for Hertz (albeit for different reasons), 'any sin destroys life, whether of the sinner, of society or of the gods ${ }^{6}$, (Hertz 1994: 33). This is why, according to my Seatown informants, when sin becomes personified as 'the power of Satan', what they see is

\footnotetext{
${ }^{5}$ While Hertz is commenting most directly upon conservative Catholic religiosity, the theological common ground here with Scots-Protestantism (specifically regarding Brethren articulations of the doctrine of sin as that which produces eternal death and damnation) is marked.

${ }^{6}$ Indeed, in the case of Christianity, sin can be seen as that which (albeit temporarily) destroyed the life of God, insofar as it was 'the sin problem' (described thus by my informants) which demanded the crucifixion of Christ.
} 
'the hopelessness of man's position away from God'; sin, in this folk-theology, if left untreated, brings only the certainty of death. Where, then, is the hope of expiation? How might society be cured of this 'sin sickness'? For Hertz, (and here we note the influence of Hubert and Mauss (1898)), forgiveness is only possible 'through death and sacrifice' (Hertz 1994: 76). Indeed:

as long as the fault which cries out for vengeance and defiles the world continues to exist there can be no peace in God, nor in the Church, nor in the sinner. Only the complete eradication of the fault allows the re-establishment of a normal religious life (ibid: 74)

The specificities of the evidence Hertz cites to support this case, while interesting, are surplus to my argument here, except in his noting the existence of three near-universal ritual, rhetorical and symbolic expressions of expiation found in the ethnographic record, involving, variously: (i) washing, (ii) casting aside and (iii) burning in fire, (ibid: 85-86), all of which were strongly present in Gamrie's folk-theological imaginary. As three modes of destruction - locally articulated, for example, as sins being 'washed away by the blood of Jesus', 'burnt up by God's purifying fire', or simply being 'dropped' or 'cast away' - all such actions seem to concur with Hertz's assertion that 'the pardoning of sins... has as its direct and primary object the destruction of the sins committed by believers' (ibid: 112). So fierce is the requirement of expiation that only capital punishment is deemed sufficient - a view poetically, if starkly, articulated in Gamrie through the singing of popular 'gospel hymns'. Consider, for example, this well-known hymn that develops the theme of washing:

Lay aside the garments that are stained with sin, 
And be washed in the blood of the Lamb;

There's a fountain flowing for the soul unclean,

Oh, be washed in the blood of the Lamb!

Are you washed in the blood,

In the soul-cleansing blood of the Lamb?

Are your garments spotless? Are they white as snow?

Are you washed in the blood of the Lamb? ${ }^{7}$

Or this hymn, on themes of 'sin-sickness' and the dropping of heavy loads:

O sin-sick soul, for thy disease

Hast thou spent all, yet got no ease?

E'en though thy case may desperate be,

The Great Physician waits for thee-

Oh, come, sinner, come, and linger not, while Jesus waits for Thee!

O burdened soul - thy load may drop,

Thy burden fall, thy labour stop,

Thy step henceforth be light and free,

For Jesus bore sin's load for thee-

Oh, come, sinner, come, and linger not, while Jesus waits for Thee! ${ }^{8}$

Proceeding from these comparative ethnographic observations, Hertz arrives at his final definition of expiation:

\footnotetext{
${ }^{7}$ Words by Elisha Hoffman (1878)

${ }^{8}$ Unattributed, Hymns of Light and Love No. 728.
} 
There is expiation when certain actions, which in general are ritualistic, are able to reestablish the state of things anterior to the transgression by annulling it and by satisfying justice, without the transgressor and those near him being crushed thereby (Hertz 1994: 113)

For the Brethren of Gamrie, then, being ‘born-again' by 'accepting Christ and his crucifixion' re-establishes that which was severed at the point of 'the fall', that is, their special communion with God as his 'saved people'. Importantly, according to my informants being born-again did not mean the Christian would henceforth live a sinless life. Yet, while as a consequence of this my informants did engage in acts of confession, such acts took the form of prayers spoken aloud in public prayer meetings or other church services. When referring to the sins of 'the saved', these prayers of confession remained generic and collective - often by referring to the Fall of Man and its universal consequences - thereby avoiding mention of specific sins and individual sinners. Similarly, while I cannot comment on the silent prayers of individual Christians, I did witness more personal prayers offered in small groups within the home and on the fishing boats, where again confession of personal sin was not mentioned. Crucially, many of my Close Brethren informants remained sharply critical of other religious events, hosted by churches in Gamrie with links to Pentecostal fellowships, where detailed confessions of personal sin occurred. Such confessions usually happened during special 'testimony' meetings where born-again conversion narratives were publicly recounted, often reaching their emotional climax at the point when the speaker described their pre-conversion 'life of sin', often in somewhat gruesome detail. The Brethren objected, in particular, to what they deemed to be the overly personal nature of such narratives, which were said to inappropriately shift the emphasis of worship away from God and toward a perverse glorification of the sinner and their sins. In short, the public and semi-private confessions of 
the Brethren faithful were - in the main - applied collectively, described generically, or offered silently.

What, then, to return to my earlier point, can Gamrie's Brethren do about the sins of others of those who do 'linger' in their unsaved state, resisting the call of 'blood bought' salvation? How will the sins of a 'defiled world' be washed, burnt, or thrown away, and how might others' sins be identified as such in the first instance? And what, finally, does this tell us anthropologically and theologically - about the relationship between the "I confess" of the confiteor and the "I believe" of the credo? As stated above, answering these questions requires a return to Gamrie, and to the specificities of its case and context. And it is here, I suggest, that we see the appearance of ritual.

\section{'Signs of the Times' and Expiation in Gamrie}

The Brethren of Gamrie live in a world that is defined by the defilement of sin while they themselves have been 'saved out of the world'. As such, they understand their 'born-again' salvation to have 'removed' them from an evil world, which, while unstoppably hurtling toward its own eschatological oblivion, still manages to leave a polluting stain upon all those 'unsaved' who choose to align themselves to it in the present, and thus to its sure and certain future demise. For my informants, the evidences of such satanic realities were plain, and marked many aspects of everyday life $^{9}$, from the global financial crisis, to EU fisheries regulations, to the approval of 'gay ministers' in Scotland's national Kirk, to bad tempered children openly disobeying their parents in the village shop. All these things were held by my

\footnotetext{
${ }^{9}$ See Webster 2013c for an extended discussion of the role of the devil in Gamrie religion.
} 
informants to be 'signs of the times', that is, to be early indicators that the end of the world was soon to occur. As one Close Brethren informant explained:

We are of the race of Adam; we are born in sin. These broken cisterns of the world [offer] no satisfaction. How we feel the brevity of time as we see the day drawing nigh! It is a terrible day that we live in - a wicked, evil day! What could we put our dependence on at the present time? All the promises that man has made, they are all broken - nothing to put your trust in. Everything is crumbling; [the] political world, [the] financial world, everything!

This view was echoed by many of my other Brethren informants, the great majority of whom were deeply pessimistic about their (this-worldly) future, which they viewed in terms of moral decline. One key informant in Gamrie's Open Brethren called Freddy - a local expert on biblical prophecy and an avid follower of creationist science debates - explained his views about the evil nature of the 'end times' with reference to what he called 'the first law of thermodynamics' - a law which he understood as stating that 'things always get worse'. 'Metal rusts and wood rots', Freddy explained, 'things always get worse; they never get better'. This law, he said, was as true spiritually as it was scientifically. Contrary to the theory of evolution, then, which he said was founded on false assumptions about gradual progress, for Freddy, what was observable in everyday life was rapid degeneration:

Things have never improved - it's got worse and worse. We are just poor creatures, fallen humanity at best. The Lord Jesus knows the times and conditions we are living in, and the difficulties we face. This is the day that anything of God is cast away. The world we are living in is looking more like Sodom and it's heading for destruction and ripe for judgement. 
We ought to give thanks [to God] for providing us with salvation and everything we need for the journey home.

This last comment - that God has provided for born-again Christians all that they need to 'journey home' to heaven was of immense importance among Gamrie's Brethren, who saw it as part of their 'Christian duty' to encourage each other with such reminders as they 'suffered through' the 'dark' and 'godless' 'last days' in which they found themselves. Such encouragements were voiced during every formal ritual occasion of Brethren religious life that is, at breaking of bread services, gospel meetings, bible reading meetings, and prophecy meetings - not only in preaching, but also in prayer, and, as above, in hymn singing (cf. Wilkins 2015: 143). The 'bible reading' I quoted at the start of this article, for example, concluded with the following words of prayer - "we thank Thee that despite the attacks of the enemy [the Devil], Thy work is going on, and Thou art taking out of this world a people to Thy Name". Yet, as well as encourage each other through such rituals with thoughts of a future day when they would be taken 'out of this world', my informants also sought to caution one another with warnings about their present experience, as in these words spoken at a Close Brethren 'prophecy meeting':

Truly, beloved Brethren, we believe we are in the last days - the last of the last days. Well, beloved Brethren, we surely would be, now, in the evil day. As we look round this wicked evil world, we are surely in this times (sic).

Crucially, these eschatological sentiments were not restricted to the rituals of preaching in the pulpit or breaking bread at the Lord's Table, but were debated in the streets, on the fishing 
boats, in the harbour café, and in the home. Much of this discussion revolved around what some Christians disparagingly refer to as 'newspaper exegesis', that is, a viewing of all current events through a premillennial reading of biblical prophecy, thereby rendering the present as 'the last of the last days'. In practice, this lived exegesis amounted to an endless search for 'signs of the times' - as described above in terms of an apocalyptic reinterpretation of the global economic recession or EU fisheries legislation. More local events were also drawn into this cosmology of signs, with the British MPs' expenses scandal, or High Court rulings on 'religious liberty' cases becoming topics for fervent prayer in church and spiritualised gossip in the street. Unexpectedly harsh winters, poor fishing conditions which financially punished Sabbath-keeping, local church splits, local problems with drugs, the lax morality of 'incomers' - all such happenings were regarded as clear and undeniable 'signs of the times'.

By discussing such signs - by reading about them in newspapers, by preaching and praying against them, by gossiping about them - my Brethren informants came to accept and experience them as real eschatological events, and, in so doing, to incorporate their exterior evidential content into their own 'inner' intellectual (cf. Keller 2005) and spiritual lives as 'sincere' Protestants (Keane 2002). Thus, if the Brethren were to remain free from the polluting stains of the 'wicked evil world' they were forced to inhabit (albeit not for much longer), collective efforts to remain vigilant against its ever encroaching sin were required. The doctrine of separation was not enough, however, for it only instructed one how to act with regards to the known evils of the present. In this forward looking eschatological context, then, vigilance also required the Brethren to constantly produce new evidence for (that is, 'signs' of) the sins of others, for without this new evidence, one could not be certain of 
maintaining the collective moral purity of the assembly into the future, through pre-emptive acts of separation.

For the Brethren of Gamrie, then, identifying 'signs of the times' is not only a ritual matter of avoiding sin, it can also be seen as a ritual method by which they confess sin and confess their faith, in preaching, prayer, hymn singing, and breaking bread, as well as in the everyday rituals of sign searching, newspaper exegesis, and spiritualised gossip. Thinking of rituals of confession in this double form is helpful because it allows us to see past (and perhaps even collapse) the distinction between the "I believe" of the credo and the "I confess" of the confiteor. For my Brethren informants, then, their 'confession of faith' is essentially eschatological in nature - 'truly, beloved Brethren, we believe we are in the last days'. This belief that the present exists as 'the last of the last days' has come, in Gamrie, to monopolise the content of Christian orthodoxy; being part of 'the saved' means believing in (that is, socially and theologically internalising) the imminent arrival of the eschaton. Here, the internalisation of external 'signs of the times' helps us to see what it is, precisely, that is being internalised, namely the theology of dispensationalism and its semiotically habituated search for the impending rapture. It is for this reason, then, that the Brethren do not, by and large, view the Presbyterians in the village as 'soundly saved' - for theirs is a sin of omission, a failure to fully internalise the externality of coming apocalypse.

Yet, this ritualised 'confession of faith' - this internalised Brethren credo - is populated with and substantiated by ritualised confessions of $\sin$. Crucially, these sins are imagined to have been committed not by the Brethren community but by the 'unsaved' and 'worldly' other. Such confessions occur in church, at home, and on the boats - when the power of Satan in the 
world is admitted to, when the Fraserburgh drug problem is acknowledged, when family breakdown is discussed, when current events are analysed, when EU fishing regulations are critiqued, and when village conflicts are gossiped about. It is these exo-confessions of sinthat themselves emerge as a result of searching for external 'signs of the times' - that constitute Brethren ritual confessions of faith. Thus, the "I confess" of the confiteor and the "I believe" of credo co-constitute one another in and through such evidences of the 'lostness' of 'this present age' - evidences that are substantiated in and through the rituals of preaching, prayer, hymn singing and so on. Put simply, the Brethren confess their dispensational beliefs by confessing the sins of others.

\section{Conclusion: The credo of the confiteor}

With the gaze of confession thus turned radically outward - away from the 'saved' community and toward the 'unsaved' other - Brethren announcements of global wickedness enact, in a deliberate tautology, both a totalising call for repentance from sin, and a millenarian creed of the imminent apocalypse. Confession, in this context, does not look for forgiveness (or 'expiation'), according to the Foucauldian model, by making public that which is private, or by externalising that which is internal. Rather, among the Brethren of Gamrie, this dual symbolic classification of confession appears to move in the opposite direction, that is, by internalising external signs. Here, the starting point for confession is not an 'inner self', but rather the people, places and things that make up the 'external signs' of the sinful, even demonic, 'other' - Fraserburgh, its discarded needles, and its drug dealers for example, or Europe, its fisheries legislation, and its bureaucrats. 
In this eminently social view of confession, the semiotic puzzle (the 'problem of ritual') is no longer how that which begins as a private affair ('my hidden sins') becomes a semi-public affair ('my confession') i.e. how referents find appropriate signs. On the contrary, the puzzle addresses how external signs may actually help constitute the internal referents to which they are supposedly attached. This problem - if not its solution - is sharply observed by Carr (2013), in her analysis of Rafael's (1993) account of Tagalog confessants who:

strategically 'misinterpreted' their Spanish confessors' demand for complete confessions by disclosing the sins of friends and neighbours, refusing to be interpolated as individual subjects... Such tactics troubled the dominant Euro-American ideology that claims that language primarily functions as a transparent medium of representation. By shifting the reference-point of the confessional act, Tagalog confession also disturbed the premises of the ideology of inner reference - an ideology that suggests that words can find their referents inside speakers. After all, confessing others' sins suggests the intrinsic connectedness of people, words, and things, and performs - if not denotes - an ethic of mutual responsibility (Carr 2013: 46)

I have argued that, as in Tagalog confession, for the Brethren of Gamrie, confession of sin does not conform to 'the premises of the ideology of inner reference' (ibid). However, my claim about Brethren confession goes further, I think, than the claim made by Carr about the Tagalog. This is because the Brethren cannot be seen to 'strategically misinterpret' anything, for their model of confession is not essentially reactionary, as Carr seems to be suggesting of the Tagalog. While their starting point is, in part, 'the dominant Euro-American ideology that claims that language primarily functions as a transparent medium of representation' (ibid.), where the Brethren break from this ideology (as it is generally imagined within the 
Foucauldian paradigm) is in their identification of what is being represented. Rather than claiming that 'words can find their referents inside speakers' (ibid.), Brethren confession enacts both a confiteor and a credo whereby, through ritual, words find their referents outside speakers, as located in the external 'signs of the times' of political events, fishing management, heroin addiction and so on - all of which may be understood in the semiotic terminology of Charles Peirce as 'indexical signs' or 'reagents' (see Johansen 2002: 32) by virtue of their assertion of a real (that is, temporal and in some cases physical) connection with their object, the apocalypse.

What, finally, is the consequence of this partial break with the dominant Euro-American ideology of language? The main consequence I have attempted to highlight throughout this essay is a collapse in the distinction between the confiteor and the credo. Thus, in and through the search for 'signs of the times', Brethren confession involves both confessing the sins of others, and confessing a collective faith or 'shared set of core beliefs and values' (Wilkins 2015: 128) in the soon to arrive eschaton. But do we see among the Brethren of Gamrie what Carr sees among the Tagalog, namely 'the intrinsic connectedness of people, words, and things' as well as the performance of 'an ethic of mutual responsibility' (ibid)? The answer to the first half of this question must surely be yes, for it is people, words and things, (as well as the places they inhabit), that constitute the 'signs of the times' that, in turn, constitute the double ritual confession of confiteor and credo.

The second half of this question, regarding 'an ethic of mutual responsibility' requires a more equivocal - even problematic - affirmation because of the way in which the Brethren understand the nature of human agency and thus moral culpability. For the Brethren, there 
exist two categories of persons - 'the saved' and 'the unsaved', who, while being capable of acting in the world, never do so completely independently of the other-worldly forces that animate their being. Thus, 'persons do things that can only come from Satan himself', or, alternatively, they live a life of holy separation on the basis of God's 'providing us with salvation and everything we need for the journey home'. Moral culpability, then, is always problematic, being always sublimated through either the immanence of God or the devil (Webster 2013c. See also Furer-Haimendorf 1974: 547). Here, the 'mutuality' of responsibility finds itself separated into four (divine / saved / unsaved / demonic) categories that are then joined into two pairs, placing its 'ethic' within a double binary of human-divine versus human-demonic agency - and thus culpability.

In Gamrie, the consequences of this culpability appear demarcated in equally stark terms. Remember, here, Hertz's definition of expiation as that which, in Parkin's reading, necessarily requires 'the abolition of the past[;] ...the destruction of the sinner's sin and the elimination of evil' (Parkin 1994: 31). Mauss, who worked closely with Hertz's unfinished text while developing his own ideas on expiation and sacrifice, similarly concludes that 'the anger [generated by the fault] can only be assuaged by the destruction of its object or by any destruction whatever' (Mauss, quoted in Parkin 1994: 38). What, then, of the expiation of the confiteor? Does the Brethren credo of the soon to arrive eschaton - and its associated confession of the sins of others - produce true forgiveness? Does it solve the problem of ritual, namely, the problem of $\sin$ ?

It does, according to both Hertz and my Brethren informants, but only for 'the saved', for it is they - God's born-again, chosen people - who are able to have their sins destroyed ('washed 
in the blood') without themselves being destroyed. For those who do not heed the creed and confession of repentance before the end of the world, they too, according to the Brethren of Gamrie, will have their sins destroyed, but only as a result of 'the transgressor and those near to him being crushed thereby' (Hertz 1994: 113) in the devastation of the apocalypse - a prophetic devastation that promises to destroy not only the sinner and his sin, but also the whole world. In this last instance, the confiteor and credo of my Brethren informants produce not expiation, but, in Mauss' reading of Hertz, lustration (Mauss, quoted in Parkin 1994: 38), that is, the death of purification by sacrifice. 


\section{Bibliography}

Campbell, J. K. 1964. Honour, Family and Patronage: A Study of Institutions and Moral Values in a Greek Mountain Community. Oxford: Oxford University Press.

Carr, E. S. 2013. ' Signs of the times': confession and the semiotic production of inner truth' in Journal of the Royal Anthropological Institute 19: 34-51.

Durkheim, E. 1912. The Elementary Forms of the Religious Life. Oxford: Oxford University Press.

Faubion, J. D. 2011. An Anthropology of Ethics. Cambridge: Cambridge University Press.

Focuault, M. 1993. 'About the Beginning of the Hermeneutics of the Self: Two Lectures at Dartmouth' in Political Theory 21 (2): 198-227.

Frykholm, A. J. 2004. Rapture Culture: Left Behind in Evangelical America. Oxford: Oxford University Press.

Furer-Haimendorf, C. 1974. 'The Sense of Sin in Cross-Cultural Perspective' in Man (New Series) 9 (4): 539-556

Harding, S. F. 2000. The Book of Jerry Falwell: Fundamentalist Language and Politics. Princeton: Princeton University Press.

Hertz, R. 1960. Death and the Right Hand. London: Cohen and West.

1973. 'The Pre-eminence of the Right Hand: A Study in Religious Polarity' in Needham, R. (ed.), Right and Left: Essays on Dual Symbolic Classification. Chicago: Chicago University Press.

1994. Sin and Expiation in Primitive Societies. Oxford: British Centre for Durkheimian Studies, Occasional Papers no. 2 
Hubert, H. and Mauss, M. 1898. Sacrifice: Its Nature and Functions. London: Routledge and Kegan Paul.

Keller, E. 2005. The Road to Clarity: Seventh-Day Adventism in Madagascar. New York: Palgrave-Macmillan

Laidlaw, J. 2002. 'For An Anthropology Of Ethics And Freedom' in Journal of the Royal Anthropological Institute 8 (2): 311-332.

Nadel-Klein, J. 2003. Fishing for Heritage: Modernity and Loss Along the Scottish Coast. Oxford: Berg.

Needham, R. 1973. Right and Left: Essays on Dual Symbolic Classification. Chicago: Chicago University Press.

Parkin, R. 1994. 'Introduction' in Hertz, R. 1994. Sin and Expiation in Primitive Societies. Oxford: British Centre for Durkheimian Studies, Occasional Papers no. 2

2008. 'Robert Hertz on Suffering and Evil: The Negative Processes of Social Life and their Resolution' in Pickering, W. S. F. and Rosati, M. (eds.) Suffering and Evil: The Durkheimian Legacy. London: Berghahn.

Rafael, V. 1993. Contracting colonialism: translation and Christian conversion on Tagalog society under early Spanish rule. Durham: Duke University Press.

Robbins, J. 2012. 'On Becoming Ethical Subjects: Freedom, Constraint and the Anthropology of Morality' in Anthropology of this Century 5.

Sahlins, M. 1996. 'The Sadness of Sweetness: The Native Anthropology of Western Cosmology’ in Current Anthropology 37 (3): 395-428.

Webster, J. 2008. 'Establishing the 'Truth' of the Matter: Confessional Reflexivity as Introspection and Avowal' in Psychology and Society 1 (1): 65-76 
2013a. The Anthropology of Protestantism: Faith and Crisis among Scottish Fishermen. New York: Palgrave Macmillan.

2013b. 'The Eschatology of Global Warming in a Scottish Fishing Village' in Cambridge Anthropology 31 (1): 68-84.

2013c. 'The Immanence of Transcendence: God and the Devil on the Aberdeenshire Coast' in Ethnos: Journal of Anthropology 78 (3): 380-402

2018. 'The Exclusive Brethren 'Doctrine of Separation': An Anthropology of Theology' in Lemons, D. (ed.) Theologically Engaged Anthropology. Oxford: Oxford University Press.

Wilkins, F. 2015. 'Fishers of Men: Maritime Radio and Evangelical Hymnody in the Scottish Fishing Industry, 1950-65' in Saylor, E. and Scheer, C. M. (eds.) The Sea in the British Musical Imagination. Woodbridge: Boydell Press. 